\title{
Fate of Isolated Spills on Savannah River Site Soils
}

by

M. Denham

Westinghouse Savannah River Company

Savannah River Site

Aiken, South Carolina 29808

DOE Contract No. DE-AC09-96SR18500

This paper was prepared in connection with work done under the above contract number with the U.S. Department of Energy. By acceptance of this paper, the publisher and/or recipient acknowledges the U.S. Government's right to retain a nonexclusive, royalty-free license in and to any copyright covering this paper, along with the right to reproduce and to authorize others to reproduce all or part of the copyrighted paper.
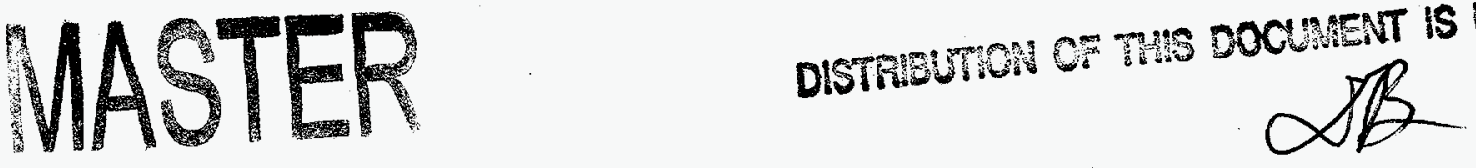
WSRC-TR-98-00008, Rev. 1

Publication Date: April 1998

\section{Fate of Isolated Spills on Savannah River Site Soils (U)}

M. E. Denham

Savannah River Technology Center

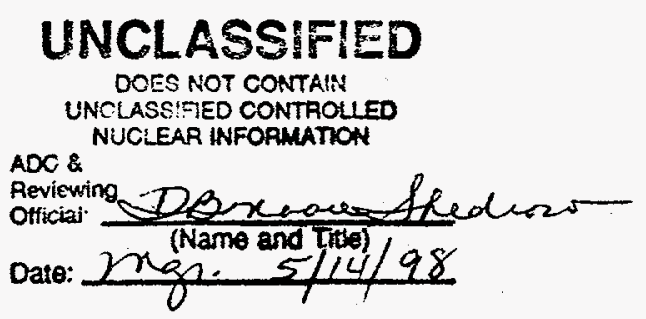

Westinghouse Savannah River Company

Savannah River Site

Aiken, South Carolina 29808 


\section{DISCLAIMER}

This report was prepared as an account of work sponsored by an agency of the United States Government. Neither the United States Government nor any agency thereof, nor any of their employees, makes any warranty, express or implied, or assumes any legal liability or responsibility for the accuracy, completeness, or usefulness of any information, apparatus, product, or process disclosed, or represents that its use would not infringe privately owned rights. Reference herein to any specific commercial product, process, or service by trade name, trademark, manufacturer, or otherwise does not necessarily constitute or imply its endorsement, recommendation, or favoring by the United States Government or any agency thereof. The views and opinions of authors expressed herein do not necessarily state or reflect those of the United States Government or any agency thereof.

This report has been reproduced directly from the best available copy.

Available to DOE and DOE contractors from the Office of Scientific and Technical Information, P.O. Box 62, Oak Ridge, TN 37831; prices available from (615) 576-8401.

Available to the public from the National Technical Information Service, U.S. Department of Commerce, 5285 Port Royal Road, Springfield, VA 22161. 


\section{DISCLAIMER}

Portions of this document may be illegible electronic image products. Images are produced from the best available original document. 
Table of Contents

List of Figures

List of Tables

Introduction

Acid and Base Spills

Sodium Hydroxide/Caustic Spills

Aluminum Nitrate Spills

Potassium Permanganate Spills

Sodium Metabisulfite Spills

Alcohol Spills

References

\section{$\underline{\text { Page }}$}

ii

iii

1

1

7

8

8

9

9

10 
Figure 1: Solubility curves for gibbsite, goethite, and kaolinite vs. $\mathrm{pH}$.

Figure 2: Estimated titration curve of a $50 \mathrm{wt.} \% \mathrm{HNO}_{3}$ solution (initial $\mathrm{pH}=-0.18$ ) by kaolinite.

Figure 3: Estimated titration curve of a solution of $\mathrm{HNO}_{3}$ with $\mathrm{pH}=1.8$. 
List of Tables

Table 1: Health Based Limits for Common Acid Anions in Groundwater and Soil
Page 


\section{Introduction}

This memorandum addresses whether there is a technical basis for discontinuing the tracking of sites where isolated spills of particular chemicals onto Savannah River Site (SRS) soils occurred. The chemicals of interest are nitric acid, hydrochloric acid, sulfuric acid, phosphoric acid, sodium hydroxide/caustic solutions, aluminum nitrate solution, potassium permanganate solution, sodium metabisulfite solution, and alcohol. The types of spills discussed include one-time operations incidents where a chemical was spilled at a facility or from bottles, drums, or tankers during transportation. The facts presented apply less to sites where multiple spills have occurred (e.g. beneath caustic tanks) and do not apply to continuous sources such as seepage basins.

When spilled onto soils, the chemicals discussed in this document undergo chemical or biological reactions that tend to mitigate the hazard associated with the pure chemical. The $\mathrm{pH}$ of the acids (hydrochloric, nitric, phosphoric, and sulfuric) and bases (sodium hydroxide and caustic solution) are neutralized by reaction with soil minerals. Chloride and nitrate from hydrochloric and nitric acid are mobile in soils and will not remain concentrated at the site of a spill. Phosphate and sulfate from phosphoric and sulfuric acid are less mobile and may remain in soils at the site of a spill. However, neither of these constituents are considered to be a health hazard. Likewise, the cations of basic solutions (typically sodium, potassium, calcium, or magnesium) are not considered health hazards and their concentration at the site of a spill is generally not a concern. Aluminum nitrate solutions act as weak acids that tend to be neutralized by passage through soils. Aluminum will be adsorbed to soils or will precipitate. However, precipitation of aluminum from a $34 \mathrm{wt} \%$ solution of aluminum nitrate will not raise the aluminum concentration in soil above any risk based concentration. The oxidation hazard posed by potassium permanganate solution will be diminished by oxidation of organic matter as the solution passes through soils. This reaction will result in precipitation of manganese, which in a worst case scenario could exceed risk based concentrations in soils. Reduction of ferric iron phases in soils by sodium metabisulfite solution will decrease any hazard posed by these spills. Light molecular weight alcohols (methanol, ethanol, isopropanol, etc.) are relatively volatile and are readily degraded by microbial action in soils. Therefore, some spilled alcohol will likely evaporate to the atmosphere, while the remainder will be biodegraded as it passes through the soil. Hence, it is expected that natural processes operating over several years will have eliminated any hazard associated with isolated spills of these chemicals.

\section{Acid and Base Spills}

Spills of acids and bases onto Savannah River Site soils will generally be neutralized to acceptable $\mathrm{pH}$ levels by passage through the soils. Contact of SRS soils with concentrated acids or bases causes reactions that tend to neutralize the $\mathrm{pH}$ of the reagent. Initial and relatively rapid reactions are those that involve adsorption and desorption from surfaces of minerals in the soil. These are generally most important in neutralizing $\mathrm{pH}$ values that are relatively close to that of the soil. When soils contact solutions that have $\mathrm{pH}$ values vastly different from that of the soil, dissolution/precipitation reactions tend to 
neutralize the $\mathrm{pH}$. Thus, isolated spills of contaminant free acids and bases onto the ground are rarely threats to the environment at SRS.

Adsorption-desorption reactions affect $\mathrm{pH}$ of a solution when hydronium or hydroxyl ions are adsorbed or desorbed from mineral surfaces. For example, a sulfuric acid spill may cause desorption of hydroxyl ions because the sulfate from the acid will tend to exchange with hydroxyl ions on the surfaces of minerals. The additional hydroxyl ions in solution raise the $\mathrm{pH}$ of the acidic fluid as it passes through the soil. These reactions are relatively rapid, but are more limited in the amount of acid per mass of soil they can neutralize relative to dissolution/precipitation reactions.

SRS soils contain several phases that may contribute to neutralization of acids and bases. Ferric iron and aluminum hydroxides [e.g., $\left.(\mathrm{Fe}, \mathrm{Al})(\mathrm{OH})_{3}\right]$ and oxyhydroxides [e.g., $(\mathrm{Fe}, \mathrm{Al}) \mathrm{OOH}]$ are common in SRS soils. Likewise, kaolinite $\left[\mathrm{Al}_{2} \mathrm{Si}_{2} \mathrm{O}_{5}(\mathrm{OH})_{4}\right]$ is an abundant clay mineral in SRS soils. The amphoteric nature of the ferric iron and aluminum cations allow dissolution of these minerals to neutralize both concentrated acids and bases. Figure 1 shows the solubility curves for kaolinite, gibbsite $\left(\mathrm{Al}(\mathrm{OH})_{3}\right)$, and goethite $(\mathrm{FeOOH})$. The solubility increase of these minerals at $\mathrm{pH}$ extremes $(\mathrm{pH}<3$ and $\mathrm{pH}>8$ ) controls their ability to neutralize concentrated acids and bases.

Acidic spills will be neutralized by reaction with aluminosilicate minerals. Figure 2 shows a titration curve of nitric acid by kaolinite. Dissolution of approximately 340 grams of kaolinite will buffer the $\mathrm{pH}$ to a value of about 1.8. At $\mathrm{pH} 1.8$ the titration curve intersects the solubility curve of kaolinite and no more kaolinite can be dissolved. However, gibbsite can continue to be dissolved and the slow nucleation kinetics of kaolinite will allow continued neutralization of the acid. The titration of an acid with $\mathrm{pH}=1.8$ by gibbsite is shown in Figure 3. Only a small amount of gibbsite, about $450 \mathrm{mg}$, will neutralize the acid to a pH of 2.30 where the solubility limit of gibbsite is reached. Thus, for most isolated spills of concentrated acid, the dissolution of soil minerals can be expected to neutralize the acid to a $\mathrm{pH}$ of approximately 2.3 or above. This does not account for complexing of aluminum by the acid anion. Such complexing will increase the solubility of kaolinite and gibbsite, and thus will increase the final $\mathrm{pH}$.

At a $\mathrm{pH}$ of 2.3 the hydronium ion activity is low enough that neutralization by adsorption and anion exchange can significantly raise the $\mathrm{pH}$. For example, sulfate introduced by a spill of concentrated sulfuric acid will tend to adsorb onto mineral surfaces. The adsorption process is actually an anion exchange reaction in which hydroxyl ions are released from the mineral surface and react to neutralize the acid. At a $\mathrm{pH}$ of 2.3 the concentration of hydronium ions is about 0.005 moles/liter. Thus, in a spill of concentrated sulfuric acid that has been neutralized to a $\mathrm{pH}$ of 2.3 by mineral dissolution, the exchange of a small fraction of the sulfate with hydroxyl ions will raise the $\mathrm{pH}$ significantly higher than 2.3 . This phenomenon is illustrated in the results of experiments on the interactions of coal leachate (similar to a sulfuric acid solution of $\mathrm{pH}=2.1$ ) with SRS soils by Anderson et al. (1993). When pH 2.1 sulfuric acid was passed through 25 $\mathrm{cm} \times 2.5 \mathrm{~cm}$ columns packed with SRS soils, the first two pore volumes of solution were 


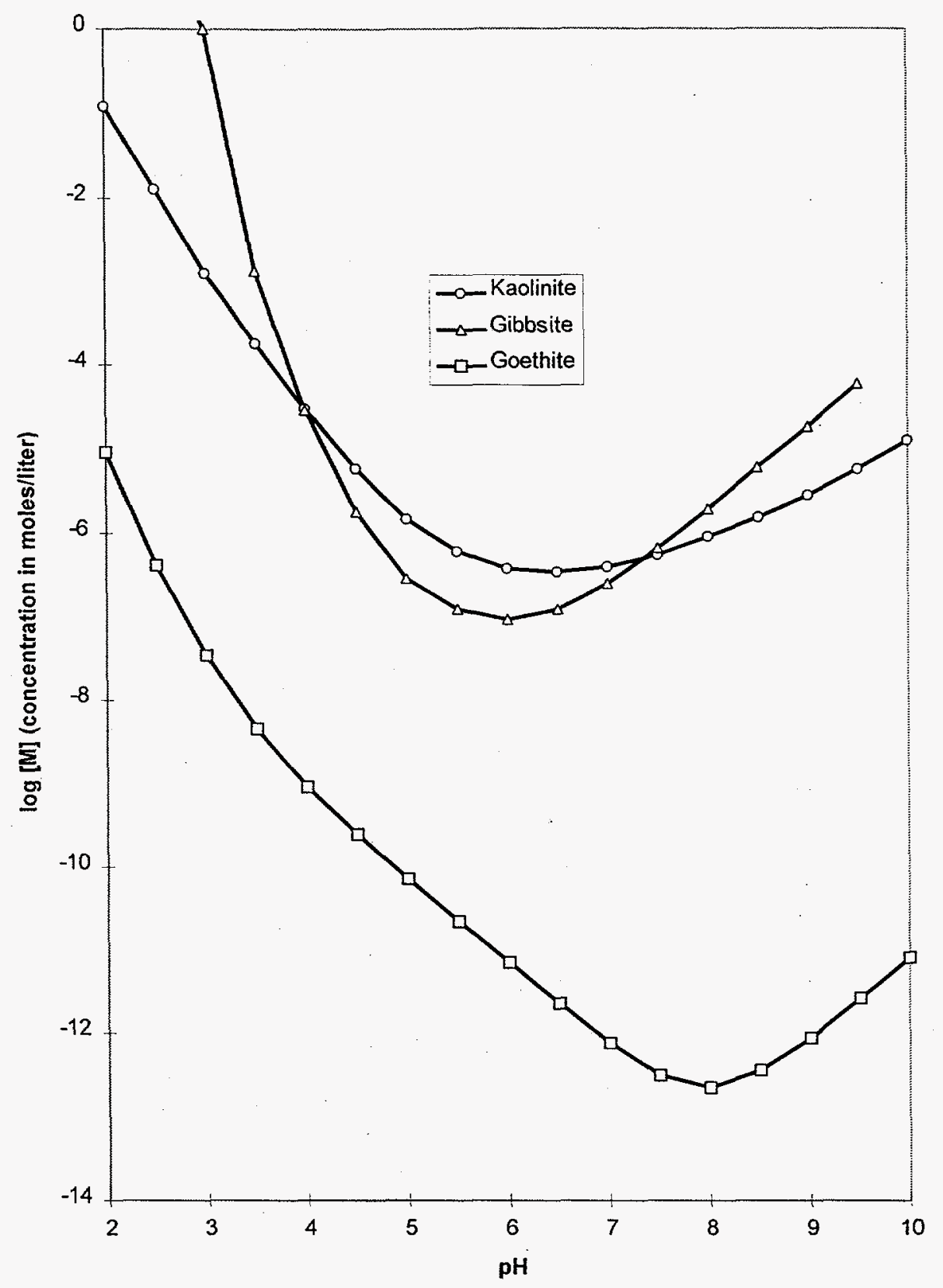

Figure 1: Solubility curves for gibbsite, goethite, and kaolinite vs. pH. Solubility expressed as the $\log [\mathrm{M}]$ where [M] is the total dissolved concentration of the metal ion (Al(III) or Fe(III)) in units of moles/liter. 


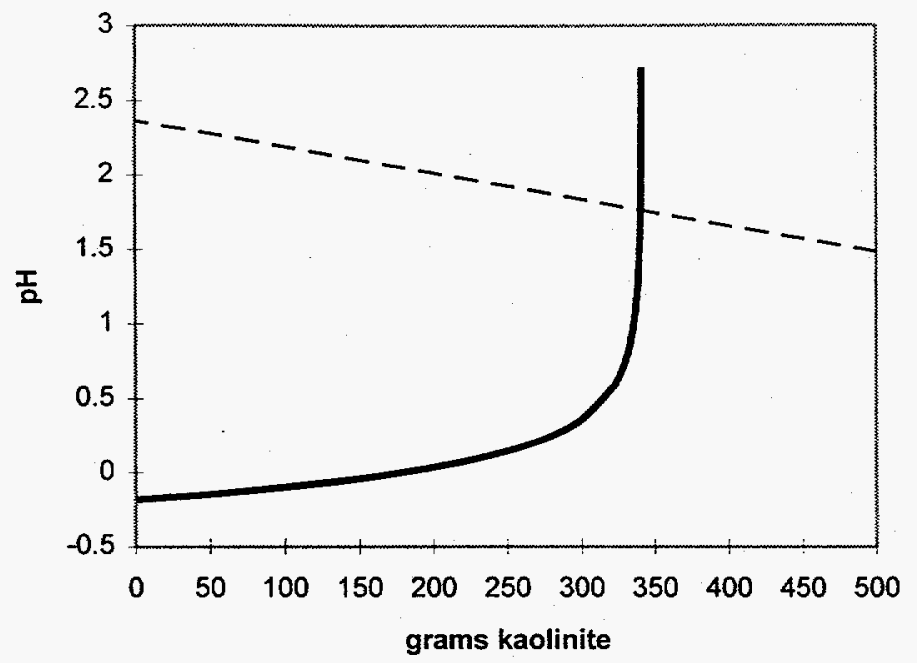

Figure 2: Estimated titration curve of a 50 wt.\% $\mathrm{HNO}_{3}$ solution (initial $\mathrm{pH}=-0.18$ ) by kaolinite. Dashed line is the solubility limit of kaolinite.

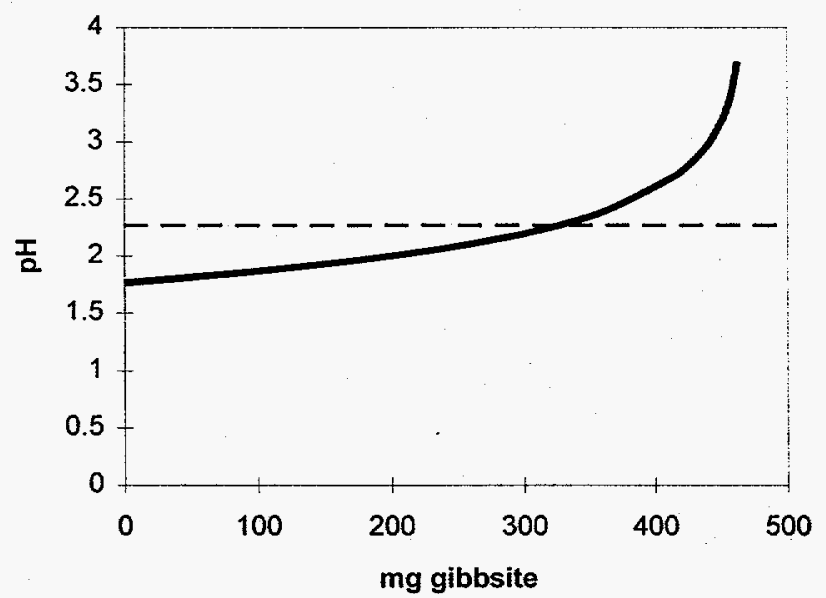

Figure 3: Estimated titration curve of a solution of $\mathrm{HNO}_{3}$ with $\mathrm{pH}=1.8$. Dashed line represents solubility limit of gibbsite assuming solubility limit for kaolinite at $\mathrm{pH}=1.8$ (340 grams/liter) has been reached. 
buffered to $\mathrm{pH}>4.5$. The molar quantity of hydronium ion neutralized was approximately equal to sulfate adsorbed to the soil.

Hence, isolated spills (point sources as opposed to continuous sources) of concentrated acid will be neutralized by reaction with soil minerals. Dissolution of kaolinite and gibbsite will raise the $\mathrm{pH}$ to a value of 2.3 or above. As the acid continues to move through the soil, adsorption and anion exchange reactions will raise the $\mathrm{pH}$ further. This analysis is consistent with experiments on SRS soils by Hoeffner (1985) from which the conclusion was drawn "that a strongly acidic spill will be neutralized within a short distance from the spill site".

To assess the travel distance required to neutralize an acid spill in SRS soil, consider a spill of $50 \%$ nitric acid solution having a pH of about -0.18 . Figures 2 and 3 show that it would take about 340 grams of dissolved kaolinite and a minor amount of gibbsite (about $450 \mathrm{mg}$ ) to neutralize each liter of acid solution to a $\mathrm{pH}$ of 2.3 . At $100 \%$ saturation in a soil with a porosity of 0.26 (Looney et al., 1987) each liter of solution would be contained in a unit soil volume of $3846 \mathrm{~cm}^{3}$. The mass of soil minerals in that volume would be about 7542 grams $\left[\left(3846-1000 \mathrm{~cm}^{3}\right) \times 2.65 \mathrm{~g} / \mathrm{cm}^{3}\right]$. If the soil consisted of $5 \mathrm{wt} \%$ kaolinite then each unit soil volume would contain 377 grams of kaolinite. If , on average, $5 \%$ of the kaolinite present is dissolved from each unit volume of soil as acid passes through, then the acid must pass through about 18 unit soil volumes to become neutralized to a pH of 2.3. Assuming each unit soil volume is a cube $15.7 \mathrm{~cm}$ on a side, then the acid will reach a $\mathrm{pH}$ of about 2.3 after migrating 2.8 meters. This only accounts for neutralization by dissolution of kaolinite and gibbsite. In addition, other common aluminum-bearing phases such as alkali feldspar react to neutralize acid. Once the $\mathrm{pH}$ has been elevated to above 2 , anion exchange can become a significant influence on $\mathrm{pH}$. The experimental results of Anderson et al. (1993) suggest that anion exchange could drive the $\mathrm{pH}$ to above 4 within another $16-32 \mathrm{~cm}$ (1-2 unit soil volumes). The assumptions in this analysis are conservative and actual distances required for neutralization may be less.

After neutralization of the acid, the main environmental concern is the fate of the acid anion. Some acid anions are mobile and will migrate with groundwater, others that are immobile will remain in the soil in the vicinity of the spill. Thus, the two environmental concerns are whether the concentrations of these anions will exceed health based limits in either groundwater or soil. Health based limits for chloride, nitrate, sulfate, and phosphate in groundwater and soil are listed in Table 1. 
Table 1: Health Based Limits for Common Acid Anions in Groundwater and Soil

\begin{tabular}{|lll|}
\hline Acid Anion & $\begin{array}{l}\text { Primary Drinking Water } \\
\text { Std. }(\mathbf{m g} / \mathbf{l})\end{array}$ & $\begin{array}{l}\text { Risk Based Conc. in Soil } \\
\mathbf{( m g} / \mathbf{k g})\end{array}$ \\
Chloride & 250 & none \\
Nitrate & 10 & $1.3 \mathrm{E}+05$ \\
Sulfate & 400 & none \\
Phosphate & none & none \\
\hline
\end{tabular}

$$
1 \text { - residential scenario }
$$

Of the four acid anions associated with acidic spills at SRS, chloride and nitrate are the most mobile in soils. Under the initial acidic conditions some adsorption of these anions will take place because of the positive surface charge imparted to mineral surfaces by the acid. Neither chloride nor nitrate form insoluble phases with the metals common in SRS soils. Thus, as fresh water from rainfall percolates through the soils chloride and nitrate will desorb. In a relatively short period of time the chloride and nitrate associated with a spill will be leached from the soil. During migration the process of dispersion further reduces the concentrations of anions associated with acidic spills. In the case of nitrate the additional process of microbial degradation can occur under anaerobic conditions. These processes not only prevent high concentrations in the soil, but also reduce the concentrations of these anions reaching the water table. This together with the small volumes of most of the spills ensure that elevated concentrations of chloride and nitrate in the water table, if they occur, will be transient and will not endanger future groundwater use.

Spills of phosphoric and sulfuric acids will result in elevated concentrations of phosphate and sulfate in soils that react with the acids. However, there are no Risk Based Concentrations (RBCs) for these constituents and they are generally considered environmentally safe in soils. Both of these acid anions will be bound in calcium, aluminum, and ferric iron phases that will precipitate as their respective acids react with soil. The phases that will precipitate are similar to materials that are in regular contact with most people. For example, Plaster of Paris and sheetrock are made of calcium sulfate minerals. Human teeth are made of a calcium phosphate compound similar to the common mineral apatite $\left[\mathrm{Ca}_{5}\left(\mathrm{PO}_{4}\right)_{3}(\mathrm{OH}, \mathrm{Cl}, \mathrm{F})\right]$. Thus, it is improbable that isolated spills of phosphoric acid or sulfuric acid would render soil a danger to human health and the environment.

Nevertheless, an estimate of the maximum concentrations of sulfate and phosphate that could result from an acid spill can be made by assuming that all of the acid anion from a 1 liter spill precipitates within the first pore volume. Using a porosity of 0.26 and a mineral density of $2.65 \mathrm{~g} / \mathrm{cm}^{3}$ (density of quartz) it can be estimated that the maximum concentration of phosphate in soil reacted with pure phosphoric acid would be $1.6 \times 10^{5}$ $\mathrm{mg} / \mathrm{kg}(16 \mathrm{wt} . \%)$. The maximum concentration of sulfate in soil reacted with sulfuric acid would be $1.9 \times 10^{5} \mathrm{mg} / \mathrm{kg}$ (19 wt.\%). It must be emphasized that these are the maximum possible concentrations. For these concentrations to be reached, all of the 
kaolinite in 1 pore volume must react with the acid. This is unlikely because as phases containing the acid anions precipitate they block access of the acid to kaolinite and reaction rates are reduced. In reality, the acid must migrate some distance through the soil to react completely.

The anions of sulfuric and phosphoric acids, sulfate and phosphate, will be attenuated by adsorption and precipitation. Phosphate forms relatively insoluble phases with cations such as aluminum, ferric iron, and calcium. Thus, high concentrations of phosphate can not be maintained in groundwater at SRS. Likewise, sulfate forms relatively insoluble phases with aluminum and ferric iron, as well as adsorbs to mineral surfaces in acidic soils. Chloride, from hydrochloric acid, forms few insoluble phases and is generally less strongly adsorbed than sulfate and phosphate. Thus, it can migrate through SRS soils more rapidly than sulfate and phosphate. Likewise, nitrate is not strongly sorbed to soils, but it can be attenuated by microbiological processes. In addition, the concentration of anions in isolated spills would be diluted by the process of dispersion during migration. Thus, it is unlikely that these acid anions would become significant threats to groundwater from point source type spills.

\section{Sodium Hydroxide/Caustic Spills}

Chemical and physical processes affect the migration of highly alkaline solutions spilled onto SRS soils. Experiments on SRS soils (Fenimore and Horton, 1968: Cook, 1981) show that high ionic strength and high $\mathrm{pH}$ solutions cause dispersal of clays that clog soil pores, reducing permeability. Cook (1981) found that above $\mathrm{pH}$ of 10 there was a substantial decrease in permeability of H-Area Seepage Basin soils. This suggests that a spill of sodium hydroxide onto SRS soils would cause a similar decrease in permeability, thus limiting the initial infiltration of the spill to a few centimeters.

Chemical reactions that neutralize the $\mathrm{pH}$ at the spill site would begin to occur during initial infiltration and would continue over time as the spill site was leached by rainfall. By stoichiometry alone the $\mathrm{pH}$ of a $50 \%$ sodium hydroxide solution is approximately 15 . At this $\mathrm{pH}$ and with exposure to atmospheric $\mathrm{CO}_{2}$, calcium and magnesium carbonate could precipitate by the reaction:

$\mathrm{Ca}^{+2}\left(\mathrm{Mg}^{+2}\right)+\mathrm{CO}_{2}+\mathrm{H}_{2} \mathrm{O}=\mathrm{CaCO}_{3}\left(\mathrm{MgCO}_{3}\right)+2 \mathrm{H}^{+}$

This reaction would decrease the $\mathrm{pH}$ if sufficient calcium and magnesium were available. Strom et al. (1994) reported that an F-Area soil contained $0.0123 \mathrm{meq} / 100 \mathrm{~g}$ of exchangeable calcium and $0.0914 \mathrm{meq} / 100 \mathrm{~g}$ exchangeable magnesium. Assuming a soil porosity of $30 \%$, then a total of approximately 6.5 meq of calcium and magnesium are available for exchange with sodium per 1 liter pore volume. Thus, some of the base would be neutralized by exchangeable calcium and magnesium. Dissolution of common silicate minerals such as biotite, glauconite, smectite, and vermiculite may provide additional calcium and magnesium allowing further neutralization of the hydroxide solution. This would further reduce the hazardous $\mathrm{pH}$. 
Other base neutralizing reactions are also likely to occur. Langton (1985) found that exposure of soil to saltstone (a mixture of alkaline salts and cement) caused dissolution of kaolinite and precipitation of hydrated sodium aluminum silicates. Braney et al. (1993) found that calcium hydroxide solutions passed through sandstone were neutralized by precipitation of hydrated calcium silicate phases. These reactions are very similar to those that occur during curing of Portland cement. Because of the similarity in chemistry, saltstone and portland cement provide good analogues to the spills of concentrated sodium hydroxide. Thus, it is likely that the long term environmental impact of an isolated sodium hydroxide spill would be similar to that caused by injection of grout into a soil.

\section{Aluminum Nitrate Spills}

Though the exact nature of the spilled aluminum nitrate solutions is unclear, there should be no environmental threat associated with these spills. A $34 \%$ aluminum nitrate solution would have a $\mathrm{pH}$ of about 3.3, and thus would not be hazardous because of low $\mathrm{pH}$. The nitrate associated with these solutions would have the same fate as nitrate associated with nitric acid spills. It would be diluted by rainfall and dispersion and some would be degraded by biological processes. As $\mathrm{pH}$ is raised by dilution and reaction with soil materials, the aluminum would precipitate removing it from solution. This decreases any hazard caused by aluminum in the migrating solution, but does increase the aluminum concentration of the soil. However, if all dissolved aluminum in a soil saturated with a 34 wt. \% solution of aluminum nitrate precipitated, the aluminum concentration in the soil would only be increased 0.6 wt. \% per 1 liter pore volume. Looney et al. (1990) observed a maximum aluminum concentration of $5.3 \mathrm{wt}$. \% in near surface soils. Even in the worst case scenario of all aluminum precipitating within one pore volume, the aluminum concentration in soil would not be elevated above any risk based limit. Thus, these spills pose no danger to the environment.

\section{Potassium Permanganate Spills}

Potassium permanganate is a relatively strong oxidizing agent. In soils it will react predominantly with organic matter to produce carbon dioxide, potassium ions, water and solid $\mathrm{MnO}_{2}$. Looney et al. (1990) found a median total organic carbon concentration of $644 \mu \mathrm{g} / \mathrm{g}$ in SRS near surface soils. Soils at the surface will contain more organic matter because of vegetation. Using $\mathrm{CH}_{2} \mathrm{O}$ as a formula for a generic natural organic compound, the reduction of permanganate ion would proceed by the reaction:

$$
1.33 \mathrm{H}^{+}+\mathrm{CH}_{2} \mathrm{O}+1.33 \mathrm{MnO}_{4}^{-}=\mathrm{CO}_{2}+1.66 \mathrm{H}_{2} \mathrm{O}+1.33 \mathrm{MnO}_{2}
$$

Thus, 1 mole of the generic organic compound can reduce 1.33 moles of permanganate ions. An organic carbon concentration in the soil of $644 \mathrm{mg} / \mathrm{g}$ is the equivalent of about 0.16 moles of the generic organic compound per mass of soil containing a 1 liter pore volume (7542 grams). If all of the organic carbon in that mass of soil reacted, then 0.21 moles of permanganate ions would be reduced per 1 liter pore volume. Reaction of permanganate with natural organic material is likely to be less efficient. If only $5 \%$ of the organic carbon per pore volume reacts, then the $6 \%$ solution would have to migrate 
through 38 pore volumes to reduce all of the permanganate. This equates to a migration distance of about 6 meters. Actual migration distances will vary depending on the reactivity of the organic matter and the presence other reductants such as ferrous iron. At SRS ferrous iron occurs in the common minerals ilmenite, glauconite, and biotite.

Precipitation of $\mathrm{MnO}_{2}$ from the reduction of permanganate will result in increased manganese concentration in the soil. If all of the manganese in 1 liter of a $6 \%$ potassium permanganate solution precipitated within the first 2 pore volumes of soil, the resulting manganese concentration would be $1400 \mathrm{mg} / \mathrm{kg}$. When this is added to natural manganese concentrations in the soil (maximum of $498 \mathrm{mg} / \mathrm{kg}$; Looney et al., 1990) it is possible that the Residential RBC of $1800 \mathrm{mg} / \mathrm{kg}$ could be exceeded. However, this is the worst case scenario. It is unlikely that all of the permanganate would be reduced within the first 2 pore volumes, for this would require very efficient reaction with organic matter.

\section{Sodium Metabisulfite Spills}

Sodium metabisulfite is a mild reducing agent used in many industrial processes and as a food preservative. When solutions of sodium metabisulfite are spilled onto SRS soils, ferric iron in the soils will be reduced by the reaction:

$$
2 \mathrm{FeOOH}_{\text {(goethite) }}+\mathrm{SO}_{3}^{-2}+\mathrm{H}^{+}=2 \mathrm{Fe}^{+2}+\mathrm{SO}_{4}^{-2}+3 \mathrm{H}_{2} \mathrm{O} \quad \log \mathrm{K}=25.65
$$

The reaction oxidizes the sulfite ion to sulfate which behaves in a similar manner to sulfate associated with sulfuric acid spills discussed above. The abundance of ferric iron phases such as goethite in SRS soils ensures that sulfite ion will not migrate far and will not accumulate in soils. Thus, isolated spills of sodium metabisulfite solution onto SRS soils in the past do not present current environmental threats.

\footnotetext{
Alcohol Spills

Small spills of alcohol do not pose a danger to the environment. Alcohol is miscible in water and will become diluted during migration. In addition, low molecular weight alcohols are readily biodegraded in soils.
} 


\section{References}

Anderson, M.A., P.M. Bertsch, and L.W. Zelazny, 1993, Multicomponent transport through soil subjected to coal pile runoff under steady saturated flow, in Trace Elements in Coal and Coal Combustion Residues, R.F. Keefer and K.S. Sajwan, eds. Lewis Publishers, Boca Raton, FL, p 137-164.

Braney, M.C., A. Haworth, N.L. Jefferies, and A.C. Smith, A study of the effects of an alkaline plume from a cementitious repository on geological materials, Journal of Contaminant Hydrology, v. 13, p. 379-402.

Cook, J.R., 1981, Study of the relationship of $\mathrm{pH}$ and permeability in the separations area seepage basins, DPST-81-935.

Fenimore, J.W. and J.H. Horton Jr., 1968, Influence of high level waste salts on movement of strontium and cesium in Savannah River Plant soil, DP-1124, E.I. du Pont de Nemours \& Co., Aiken, SC.

Freyberg, D.J., 1986, A natural gradient experiment on solute transport in a sand aquifer. 2, Spatial moments and the advection and dispersion of nonreactive tracers, Water Resources Research, v. 22, p. 2031-2046.

Langton, C.A., 1985, Preliminary results from characterization of soils in contact with saltstone - zero water flux, DPST-85-842, E.I. du Pont de Nemours \& Co., Aiken, SC.

Looney, B.B., C.A. Eddy, M. Ramdeen, J. Pickett, V. Rogers, M.T. Scott, and P.A. Shirley, 1990, Geochemical and physical properties of soils and shallow sediments at the Savannah River Site (U), WSRC-RP-90-1031, Westinghouse Savannah River Company, Aiken, SC.

Looney, B.B., M.W. Grant, and C.M. King, 1987, Estimation of geochemical parameters for assessing subsurface transport at the Savannah River Plant, DPST-85-904, E.I. du Pont de Nemours \& Co., Aiken, SC.

Strom, R.N., B.B. Looney, J.C. Seaman, P.M. Bertsch, and W.P. Miller, 1994, Summary report and report; Physicochemical and mineralogical controls on colloid migration and deposition within sediments on the Savannah River Site (U), WSRC-RP-94-276, Westinghouse Savannah River Company, Aiken, SC. 